\section{DETECCIÓN POR RT-PCR DEL VIRUS DEL AMARILLAMIENTO Y ENANISMO EN CUCURBITÁCEAS (CYSDV) DEL CENTRO-NORTE DE MÉXICO}

\section{RT-PCR DETECTION OF THE CUCURBIT YELLOW STUNT DISORDER VIRUS (CYSDV) IN THE MEXICAN NORTH-CENTRAL REGION}

\author{
María G. Álvarez-Ojeda ${ }^{1}$, César E. Guerrero-Gámez ${ }^{2}$, \\ Alberto Morales-Loredo ${ }^{3}$, Yasmín I. \\ Chew-Madinaveitia ${ }^{4}$, Hazael Gutiérrez-Mauleón ${ }^{2}$ \\ y Omar G. Alvarado-Gómez ${ }^{2 \star}$
}

\begin{abstract}
${ }^{1}$ Campo Experimental Río Bravo, Instituto Nacional de Investigaciones Forestales, Agrícolas y Pecuarias(INIFAP), Carr. Matamoros-Reynosa, km. 61, 88900 Río Bravo, Tamaulipas. ${ }^{2}$ Facultad de Agronomía, Universidad Autónoma de Nuevo León, Av. Universidad s/n Cd. Universitaria, 66451, San Nicolás de los Garza, Nuevo León. ${ }^{3} \mathrm{CDA}$ - Consorcio Técnico del Noroeste de México, A. C. Francisco Villa s/n, Norte. Col. Ex Hacienda El Canadá. 66054, Gral Escobedo, N.L. ${ }^{4}$ Campo Experimental. La Laguna, INIFAP. Blvd. Santos Valdez 1200, Poniente. 27440, Col. Centro, Matamoros, Coahuila.
\end{abstract}

*Autor para correspondencia (omar-alvarado@prodigy.net.mx)

\section{RESUMEN}

Durante los años 2008 y 2009 se muestrearon plantas de melón $(\mathrm{Cu}$ cumis melo L.), sandía (Citrullus lanatus Thumb), calabacita (Cucurbita pepo L.) y pepino (Cucumis sativus L.), así como especímenes de mosquita blanca (Bemisia tabaci Genn.) en diferentes localidades de los Estados de Nuevo León, Coahuila y Durango. Después de extraer el ARN, las muestras se analizaron con la técnica de RT-PCR, con oligonucleótidos específicos que amplifican regiones conservadas que codifican para las proteínas p22, de choque térmico y la cápside del virus del amarillamiento y enanismo de las cucurbitáceas (CYSDV). Se detectó el virus CYSDV en plantas de melón y sandía, así como mosquita blanca colectada en varias localidades. Se encontraron 26 muestras positivas al virus CYSDV de 129 plantas de la familia Cucurbitaceae en los tres estados estudiados de la región Norte-Centro de México. Los productos de amplificación fueron clonados y secuenciados, y se compararon con las secuencias disponibles en el GenBank. Las secuencias obtenidas a partir de las muestras positivas presentaron de 96 a $100 \%$ de similitud con secuencias de Estados Unidos, España y otros países.

Palabras clave: Cucurbitaceae, RT-PCR, CYSDV, Crinivirus.

\section{SUMMARY}

In 2008 and 2009, samples of melon (Cucumis melo L.), watermelon (Citrullus lanatus Thumb), pumpkin (Cucurbita pepo L.), and cucumber (Cucumis sativus $\mathrm{L}$.) plants, as well as specimens of white fly (Bemisia tabaci Genn.) from different regions in the states of Nuevo León, Coahuila and Durango, México, were collected. After RNA isolation, the samples were analyzed by RT-PCR using specific primers to amplify p22, heat shock and capsid proteins, for the cucurbit yellows stunt disorder virus $(C Y S D V)$. CYSDV virus was detected in melon, watermelon and white fly collected in several regions. Twenty-six samples turned out to be positive for the CYSDV virus out of 129 Cucurbitaceae plants in the tree states studied of the North-Central of México. The
PCR products were cloned and sequenced, and then compared with the available sequences of the GenBank. Sequences obtained from the positive samples had 96 to $100 \%$ of similarity with samples from the United States, Spain and other countries.

Index words: Cucurbitaceae, RT-PCR, CYSDV, Crinivirus.

\section{INTRODUCCIÓN}

La familia Cucurbitaceae comprende cultivos hortícolas importantes que se siembran en varios estados de la República Mexicana entre los cuales destacan Coahuila y Durango. Entre las enfermedades que afectan a esta familia en México, se encuentra la ocasionada por el virus del amarillamiento y enanismo de las cucurbitáceas (CYSDV), que causa bajos rendimientos y mala calidad del fruto, lo que ocasiona pérdidas en la producción y reducción del valor económico por la apariencia de los frutos.

El CYSDV es un miembro del género Crinivirus de la familia Closteroviridae. El genoma de este virus está compuesto por una cadena de ARN bipartita encapsulada en una partícula de filamento largo y flexible. Este virus se localiza en el floema y fue identificado por primera vez en Arabia Saudita; posteriormente fue reportado en ciudades del Medio Oriente y del Mediterráneo (Sinclair y Crosby, 2002). El CYSDV fue introducido a Texas, Arizona y California en Estados Unidos, y también está presente en Guatemala (Brown et al., 2007).

Durante el año 2006 se presentó un problema de amarillamiento en algunas áreas de Caborca y Hermosillo en el Estado de Sonora, en los cultivos de melón (Cucumis melo L.) y sandía (Citrullus lanatus Thumb.), que mostraron clorosis intervenal en las hojas más desarrolladas y del nivel medio de la planta, en las que se comprobó la presencia del virus CYSDV (Brown et al., 2007).

La técnica de la reacción en cadena de la polimerasa en tiempo real (RT-PCR, por sus siglas en inglés) ha sido de utilidad para amplificar los genomas virales compuestos de ARN, mediante el uso de oligonucleótidos específicos que amplifican genes de varias proteínas, especialmente de la cápside (Sambrook y Russell, 2001). Debido a la observación recurrente de plantas de la familia Cucurbitaceae con síntomas similares a los descritos, en zonas productoras de la región Norte-Centro de México, además de los pocos trabajos reportados a la fecha, el objetivo del presente estudio fue detectar al virus CYSDV mediante las técnicas de RTPCR punto final y tiempo real, así como secuenciación de $\mathrm{ADN}$ en muestras vegetales y en especímenes de mosquita blanca (Bemisia tabaci Genn.) colectadas en varias localidades de los estados de Nuevo León, Coahuila y Durango. 


\section{MATERIALES Y MÉTODOS}

\author{
Material vegetal
}

Durante los años 2008 y 2009, se hicieron varios muestreos de plantas de melón (C. melo L.) variedades 'Cantaloupe' y ‘Gota de miel', sandía (C. lanatus Thumb), calabacita (Cucurbita pepo L.) y pepino (Cucumis sativus L.) en zonas productoras en los municipios de Cadereyta Jiménez, Salinas Victoria, Anáhuac y Marín, en el Estado de Nuevo León; en Matamoros, Viesca y Benito Juárez, en el Estado de Coahuila; así como en Mapimí, Estado de Durango. Se colectaron 129 muestras vegetales en total, en diversas etapas fenológicas de la planta, todas ellas de plantas que presentaban los síntomas característicos de la enfermedad, tales como: malformación, amarillamiento, enanismo, deformación en frutos, etc. También se colectaron especímenes de mosquita blanca (B. tabaci Genn.) en Matamoros, Coahuila. Todas las muestras fueron procesadas y analizadas en laboratorio para su posterior interpretación.

\section{Extracción de ARN}

La extracción del ácido ribonucleico de las muestras vegetales de melón, sandía, calabacita y pepino, se hizo a partir de ápices de las plantas, con el reactivo Trizol ${ }^{\circledR}$ (Invitrogen $\left.{ }^{\circledR}\right)$. En los especímenes de mosquita blanca se utilizó el kit de extracción de ARN total SV de Promega ${ }^{\circledR}$. Ambos procesos se hicieron conforme a las indicaciones de los fabricantes.

\section{Reacciones de RT-PCR}

Para las reacciones de RT-PCR se utilizó como control positivo el ARN de una muestra enferma con el CYSDV proporcionada por la empresa Biociencia, S.A. de C.V. Se efectuó un protocolo de RT-PCR con los oligonucleótidos que se unen a los genes que codifican para la proteína 22 (p22) y se obtuvo un producto de 567 pares de bases (pb), MA156 5'-GAAGAATTCCAGGCAAGG-3' y MA129 5'-TCACATCATCAATCCAAAAG-3'; proteína de choque térmico (HSP70) con un producto esperado de $456 \mathrm{pb}$ 410L 5'-TTGGGCATGTGACAT-3' y 410U 5'-AGAGACGGTAAGTAT-3'; y cápside proteica del CYSDV (CP), CYSDVf 5'-ATGGCGAGTTCGAGTGAGAATAA-3' y CYSDVr 5'-ATTACCACAGCCACCTGGTGCTA-3' que amplifican un fragmento de 756 pb (Célix et al., 1996; Marco et al., 2003).

La síntesis de $\mathrm{ADN}$ complementario (ADNc) se hizo a partir del ARN total; para esto se agregó el oligonucleótido complementario, los desoxinucleótidos trifosfatados (dNTP's) y el ARN total (virus y planta). La mezcla se incubó a $65^{\circ} \mathrm{C}$ durante 5 min y se dejó 15 min en hielo, des- pués se agregó amortiguador $5 \mathrm{X}$, DTT $0.1 \mathrm{M}$ y la enzima M-MLV reverso transcriptasa; por último se incubó a $25^{\circ} \mathrm{C}$ por $10 \mathrm{~min}, 37^{\circ} \mathrm{C}$ durante $50 \mathrm{~min}$, y se inactivó a $70^{\circ} \mathrm{C}$ por 15 min. La PCR se llevó a cabo con una mezcla de reacción en un volumen final de $25 \mu \mathrm{L}$, cuyos componentes fueron: $5 \mu \mathrm{L}$ de amortiguador de reacción $5 \mathrm{X}, 2 \mu \mathrm{L}$ de dNTP's 10 $\mathrm{mM}, 1 \mu \mathrm{L}$ de cada oligonucleótido a 25 pmoles (antisentido

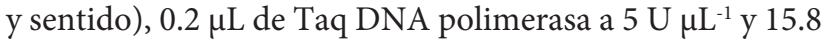
$\mu \mathrm{L}$ de agua libre de nucleasas. Las reacciones de PCR con los oligonucleótidos $410 \mathrm{U} / 410 \mathrm{~L}$ se hicieron con el programa $92-46-72{ }^{\circ} \mathrm{C}$ durante $30-30-30$ s y 35 ciclos, y en el caso de los oligonucleótidos MA129/MA156 se siguió el programa $92-58-72{ }^{\circ} \mathrm{C}$ durante $30-30-30$ s por 35 ciclos. En ambos casos se dio una extensión final de $10 \mathrm{~min}$ a $72{ }^{\circ} \mathrm{C}$. Los productos de las reacciones de PCR fueron separados por electroforesis en geles de agarosa a $1.5 \%$, y las bandas se observaron en un transiluminador de luz ultravioleta marca UVP® (California, USA).

La detección del CYSDV en mosquita blanca se hizo por RT-PCR tiempo-real con los oligonucleótidos CYScp1F 5'-GCA CGG TGA CCA AAA GAA G-3' y CYScp1R 5'GAA CAT TCC AAA ACT GCG G-3' que se unen al gen de la cápside, y amplifican un fragmento de $205 \mathrm{pb}$ (Kuo et al., 2007). El reactivo utilizado para este ensayo fue SYBR Green (Applied Biosystem ${ }^{\circledR}$ ). El programa térmico que se utilizó fue $95^{\circ} \mathrm{C}$ por $10 \mathrm{~min}, 40$ ciclos de $95^{\circ} \mathrm{C} 1 \mathrm{~min}, 63$ ${ }^{\circ} \mathrm{C} 1 \mathrm{~min}$, y se hizo una curva de disociación con las temperaturas siguientes: $95^{\circ} \mathrm{C}$ por $15 \mathrm{~s}, 60^{\circ} \mathrm{C}$ por $30 \mathrm{~s}$ y $95^{\circ} \mathrm{C}$ por $15 \mathrm{~s}$; las cantidades finales de ADNc utilizadas fueron de 22.5 y $225 \mathrm{ng}$.

\section{Clonación y secuenciación de los productos de PCR}

Los fragmentos amplificados por PCR fueron clonados en el plásmido pCR TOPO-4 (Invitrogen ${ }^{\circledR}$ ) y transformados con Escherichia coli cepa DH5a. La secuenciación se hizo con un kit Big Dye Terminador v3.1 en un equipo ABI PRISM 3100 (Applied Biosystem $®$ ). Los resultados fueron comparados con las secuencias disponibles en el banco de genes (GenBank) del Centro Nacional de Información Biotecnológica (NCBI, por sus siglas en inglés) del Instituto Nacional de Salud (NIH, por sus siglas en inglés) de Estados Unidos.

\section{RESULTADOS Y DISCUSIÓN}

\section{Ocurrencia del virus CYSDV en muestras vegetales}

Todas las muestras colectadas en los municipios de Cadereyta Jiménez y Salinas Victoria en el Estado de Nuevo León resultaron negativas al virus, lo cual se puede deber a la escasa presencia de mosquita blanca (vector), a la aplicación frecuente de insecticidas, o porque aún no está presente el virus 
en esta región; en cambio se obtuvo una muestra positiva en melón y dos en sandía de las plantas colectadas en Anáhuac, N.L. (Figura 1, Cuadro 1). Es importante destacar que el cultivo de melón en esta localidad presentaba síntomas de amarillamiento y presencia de plagas y enfermedades, y tanto en melón como en sandía se observó abundante presencia de mosquita blanca.

Las muestras colectadas en la región de Matamoros y Viesca, Coahuila fueron en su mayoría positivas al CYSDV (50 y $77 \%$, respectivamente), confirmadas mediante RTPCR con oligonucleótidos que amplifican el gen de la proteína p22 (Figura 2). En la localidad de Mapimí, Durango sólo se colectaron dos muestras de melón cv. 'Gota de miel' $\mathrm{y}$ ambas fueron positivas al virus (Cuadro 1).

En general, de las 129 muestras de calabacita, melón, sandía y pepino recolectadas en ocho localidades de igual número de municipios de los Estados de Nuevo León, Coahuila y Durango durante los ciclos agrícolas verano-otoño del año 2008 y primavera-verano del 2009, 26 muestras fueron positivas, lo que representa $20 \%$ de las muestras analizadas (Cuadro 1). Únicamente en las localidades de Cadereyta Jiménez, Salinas Victoria y Marín, en Nuevo León así como Benito Juárez, Coahuila, no se detectó el virus en las muestras analizadas. Se detectó la presencia del virus en el ciclo verano-otoño del 2008, pero no en ciclo primavera-verano del 2009. Wintermantel et al. (2009) también observaron

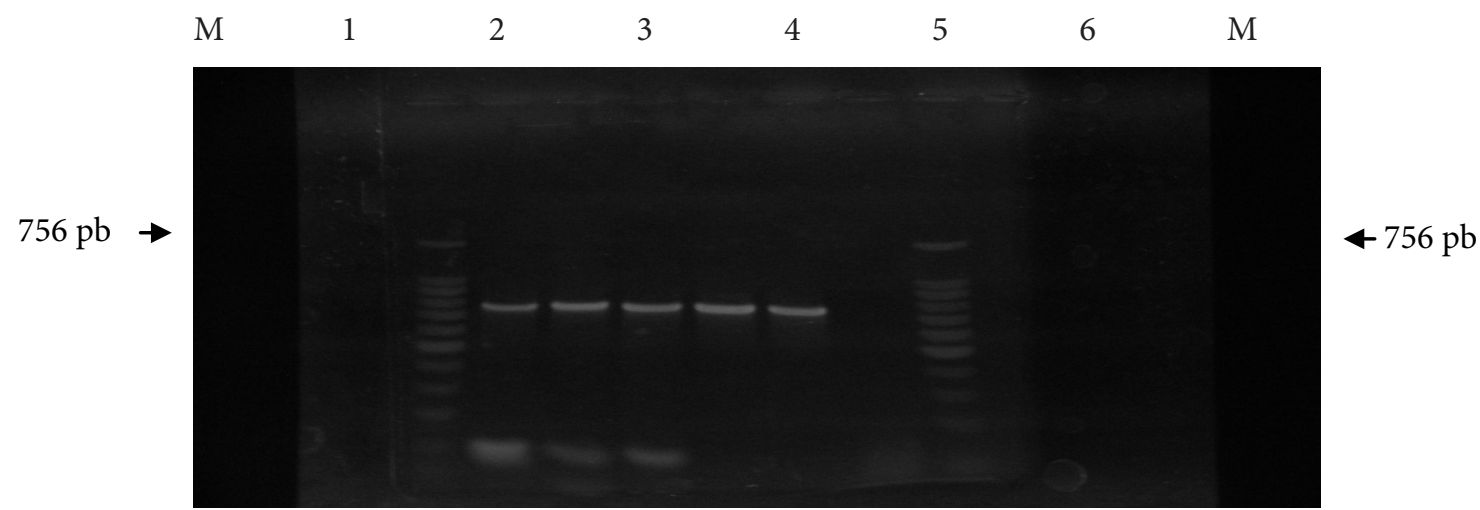

Figura 1. Electroforesis en gel de agarosa de los productos de RT-PCR de muestras de melón y sandía colectadas en el Estado de Nuevo León. Carriles 1 y 2 son muestras de melón, y carril 3 es sandía, colectadas en Anáhuac, N.L. Carriles 4 y 5 son controles positivos, carril 6 control negativo, y M marcador de peso molecular de 100 pb.

Cuadro 1. Incidencia del CYSDV en cucurbitáceas colectadas en varias localidades de México durante los ciclos verano-otoño 2008 y primavera-verano 2009.

\begin{tabular}{|c|c|c|c|c|}
\hline Estado & Municipio & Cultivo & Muestras + / Total & Muestras + (\%) \\
\hline \multirow[t]{8}{*}{ Nuevo León } & Cadereyta Jiménez & Calabacita & $0 / 14$ & 0 \\
\hline & & Melón 'Cantaloupe’ & $0 / 15$ & 0 \\
\hline & & Pepino & $0 / 8$ & 0 \\
\hline & Salinas Victoria & Melón 'Cantaloupe' & $0 / 15$ & 0 \\
\hline & Anáhuac & Melón 'Cantaloupe’ & $3 / 12$ & 25 \\
\hline & & Sandía & $2 / 9$ & 22 \\
\hline & Marín & Melón 'Cantaloupe’ & $0 / 9$ & 0 \\
\hline & & Sandía & $0 / 7$ & 0 \\
\hline \multirow[t]{3}{*}{ Coahuila } & Matamoros & Melón 'Cantaloupe' & $9 / 18$ & 50 \\
\hline & Viesca & Melón 'Cantaloupe’ & $10 / 13$ & 77 \\
\hline & Benito Juárez & Melón 'Cantaloupe' & $0 / 7$ & 0 \\
\hline \multirow[t]{2}{*}{ Durango } & Mapimí & Melón 'Gota de Miel' & $2 / 2$ & 100 \\
\hline & & Total & $26 / 129$ & 20 \\
\hline
\end{tabular}




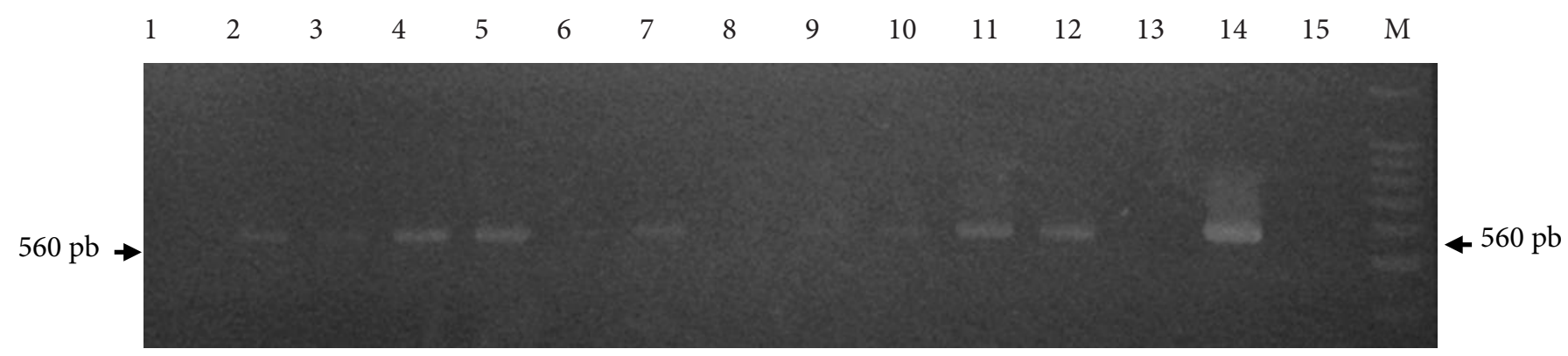

Figura 2. Electroforesis en geles de agarosa de los productos de RT-PCR de muestras de melón de Matamoros y Viesca, Coahuila. Carriles 1-12 son muestras de melón, carriles 13 y 15 son controles negativos, carril 14 es control positivo, $M$ es marcador de peso molecular de $100 \mathrm{pb}$.

una menor incidencia del virus CYSDV en el sur de California en el ciclo de primavera, comparado con una mayor incidencia en otoño. Una posible explicación sobre la diferencia en la ocurrencia del CYSDV entre los ciclos agrícolas pueda ser atribuida a la ocurrencia del vector, la mosquita blanca, la cual a su vez está influenciada por las condiciones climáticas y por la aplicación de insecticidas, principalmente. Lo anterior fue corroborado con las detecciones del $C Y S D V$ en especímenes de mosquita blanca recolectados en localidades con muestras vegetales positivas al virus.

Los primeros reportes de la enfermedad causada por el virus CYSDV en México son recientes; en el año 2006 se reportó su incidencia en cultivos de melón, calabaza y pepino, y en la arvense "meloncillo coyote" (Apodanthera undulata A. Gray) en Caborca, Hermosillo y Guaymas, Sonora; y en el año 2007 en Guaymas, Valle del Yaqui, y la costa de Hermosillo, Sonora (Moreno-Bedoy y Figueroa-López, 2008, Coms. Pers. ${ }^{1}$ ). Por lo anterior, los resultados del presente estudio representan el primer reporte de la incidencia del CYSDV en cultivos de cucurbitáceas en los Estados de Nuevo León, Coahuila y Durango, lo que evidencia la diseminación del virus.

\section{Detección del CYSDV en mosquita blanca}

La detección del CYSDV en mosquita blanca mediante PCR en tiempo-real fue satisfactoria con el kit de SYBR Green ${ }^{\circledR}$ de Applied Biosystem; las muestras en las que se encontró el virus fueron colectadas en la región de Matamoros, Coahuila.

Con la adición de ambas cantidades de ADNc 22.5 ng y de 225 ng se logró la detección del virus mediante esta técnica.

\footnotetext{
${ }^{1}$ Moreno-Bedoy A, P Figueroa-López (2008) Virus del amarillamiento y enanismo de las cucurbitáceas (CYSDV) detectado en el sur de Sonora, México. Memorias del XXXV Congreso de la Sociedad Mexicana de Fitopatología.
}

\section{Secuenciación}

Las secuencias de los fragmentos de ADN de las clonas obtenidas en el presente trabajo mostraron de 96 a $100 \%$ de identidad comparadas con la secuencia de Arizona, E.E. U.U. y España, reportadas en el banco de genes del NCBI.

\section{CONCLUSIONES}

Como resultado del trabajo experimental de campo y laboratorio, así como las comparaciones de secuencias con programas de cómputo especializado, se concluye que los oligonucleótidos utilizados para la amplificación del ADN que codifica para las proteínas HSP70, p22 y CP fueron efectivos en la detección del virus del amarillamiento y enanismo de las cucurbitáceas por RT-PCR. Mediante la técnica RT-PCR punto final se determinó la ocurrencia del virus CYSDV en lotes comerciales de melón 'Cantaloupe', 'Gota de miel' y sandía colectados en los estados de Nuevo León, Coahuila y Durango, y mediante RT-PCR en especímenes de mosquita blanca con la tecnología del SYBR Green ${ }^{\circledR}$. Se obtuvo un porcentaje de identidad de 96 a 100 $\%$ entre los fragmentos amplificados de muestras obtenidas de los municipios de Anáhuac, N.L., Matamoros y Viesca, Coahuila, y Mapimí, Durango, con la cepa de Arizona, E.E.U.U.

\section{BIBLIOGRAFÍA}

Brown J K, J C Guerrero, M Matheron, M Olsen, M A Idris (2007) Widespread outbreak of Cucurbit yellow stunting disorder virus in melon, squash and watermelon crops in the Sonoran desert of Arizona and Sonora Mexico. Plant Dis. 91:773.

Célix A, A López-Sesé, N Almarza, M L Gómez-Guillamón, E Rodríguez-Cerezo (1996) Characterization of cucurbit yellow stunting disorder virus, a Bemisia tabaci-transmitted Closterovirus. Phytopathology 86:1370-1376.

Kuo Y-W, M R Rojas, R L Gilbertson, W M Wintermantel (2007) First report of Cucumber yellow stunting disorder virus in California and Arizona, in association with Cucurbit leaf crumple virus and Squash leaf curl virus. Plant Dis. 91:330.

Marco, C F, J M Aguilar, J Abad, M L Gómez-Guillamón, M A Aranda (2003) Melon resistance to Cucurbit yellow stunting disorder virus is characterized by reduced virus accumulation. Phytopathology 93:844-852.

Sambrook J, D W Russell (2001) Molecular Cloning: A Laboratory Manual. 3rd ed. Cold Spring Harbor Laboratory Press. New York. 
Sinclair J W, K M Crosby (2002) A review of cucurbit yellow stunting disorder virus (CYSDV) a "new" virus affecting melons in the lower Rio Grande valley. Subtrop. Plant Sci. 54:54-58.
Wintermantel, W M, L L Hladky, A A Cortez, E T Natwick. (2009) A new expanded host range of cucurbit yellow stunting disorder virus includes three agricultural crops. Plant Dis. 93:685-690. 